JURNAL RESPIRASI

\title{
Biomarker Pernapasan pada Penyakit Paru
}

\author{
Novita Maulidiyah, Muhammad Amin \\ Departemen Pulmonologi dan Ilmu Kedokteran Respirasi, Fakultas Kedokteran Universitas Airlangga/RSUD Dr Soetomo
}

\begin{abstract}
Breath analysis provides a convenient and simple alternative to traditional specimen testing in clinical laboratory diagnosis. As such, substantial research has been devoted to the analysis and identification of breath biomarkers. Development of new analytes enhances the desirability of breath analysis especially for patients who monitor daily biochemical parameters. Elucidating the physiologic significance of volatile substances in breath is essential for clinical use. This review describes the use of breath biomarkers in diagnosis of asthma, chronic obstructive pulmonary disease (COPD), cystic fibrosis (CF), lung cancer, as well as other pulmonary diseases. $A$ number of breath biomarkers in lung pathophysiology will be described including nitric oxide (NO), carbon monoxide (CO), hydrogen peroxide $\left(\mathrm{H}_{2} \mathrm{O}_{2}\right)$ and other hydrocarbons.
\end{abstract}

Key word: nitric oxide, hidrogen peroxide, pulmonary disease

\section{PENDAHULUAN}

Biomarker belum memiliki definisi yang universal, akan tetapi biomarker dipahami sebagai suatu biomolekul yang timbul akibat suatu proses fisiologi maupun patologi. Biomarker yang ideal adalah suatu biomarker yang tidak dapat dideteksi atau nilainya rendah dalam keadaan non inflamasi, dan akan meningkat dalam keadaan inflamasi yang selanjutnya akan mengalami penurunan saat proses inflamasi mereda. ${ }^{1}$

Biomarker pernapasan adalah indikator fisik, fungsional dari proses fisiologis maupun patologi dari saluran pernapasan. Napas yang dihembuskan terdiri dari dua komponen, pertama adalah udara dari dead space yang tidak terjadi pertukaran gas antara darah dan udara. Kedua adalah pernapasan dari alveolar paru yang didapatkan pertukaran gas pada darah dan udara. Udara pernapasan terdiri campuran nitrogen $\left(\mathrm{N}_{2}\right)$, oksigen $\left(\mathrm{O}_{2}\right)$, karbon dioksida $\left(\mathrm{CO}_{2}\right)$, uap air $\left(\mathrm{H}_{2} \mathrm{O}\right)$, dan ratusan sampai ribuan senyawa yang mudah menguap atau senyawa Volatile Organic Compounds (VOC) dengan konsentrasi ppm (parts per million) sampai ppt (parts per trillion). ${ }^{1,2,3}$

Biomarker pernapasan merupakan suatu sarana yang mudah dan sederhana digunakan sebagai pemeriksaan spesimen di laboratorium penunjang diagnostik. Biomarker pernapasan digunakan dalam mendiagnosa berbagai penyakit seperti asma, penyakit paru obstruktif kronik (PPOK), kanker paru, serta penyakit paru lainnya.,
Dalam makalah ini akan membahas tentang biomarker pernapasan $\mathrm{NO}$, dan $\mathrm{H}_{2} \mathrm{O}_{2}$ pada penyakit paru asma, dan PPOK.

\section{Oksida Nitrat}

Oksida nitrat (NO) adalah molekul gas yang diproduksi oleh sel, saluran udara perifer serta alveoli termasuk sel epitel saluran pernapasan, sel endotel pada peredaran darah, dan sel inflamasi. NO dihasilkan dari tiga NO sintesa (NOS) isoenzim yaitu neuronal NOS (NOS1 atau nNOS), endotel NOS (NOS3 atau eNOS) dan induksi NOS (NOS2 atau iNOS). Setiap isoenzim mempunyai peranan patologis yang berbeda disebabkan oleh karena perbedaan regulasi dan ekspresi dalam saluran pernapasan. Semua isoenzim NOS mengonversi L-arginin dan NADPH kemudian menghasilkan L-citruline dan NO. ${ }^{5}$

Konstitusi NOS (cNOS) merupakan isoenzim yang mengandung NOS1 dan NOS3 dan menghasilkan jumlah kecil NO (kisaran pmol). Aktifasi NOS1 dan NOS3 tergantung pada senyawa kalsium terkait efek pro-inflamasi. NOS (iNOS or NOS2) diinduksi oleh kalmodulin dan aktif pada basal kadar kalsium sitosol. Namun, dalam jumlah yang besar NO (kisaran nmol) diproduksi oleh NSO2, sitokin pro-inflamasi, dan induksi lipopolisakarida dari bakteri. NSO2 juga bisa dihasilkan dari jenis sel lain seperti makrofag alveolar, eosinofil, dan sel inflamasi. Kortikosteroid sebagai antiinflamasi dihambat oleh NSO2 pada hewan percobaan akan tetapi 
tidak menghambat secara langsung pada epitel saluran pernapasan manusia. ${ }^{5}$

NSO3 pada umumnya bekerja pada sel endotel bronkial, endotel alveolar dan sel epitel saluran pernapasan sehingga mengaturaliran pembuluh darah setelah distimulasi oleh sitokin, endotoksin, dan LPS invitro. Selain itu, NSO3 mempunyai fungsi untuk mengurangi eksudasi plasma dalam saluran pernapasan dan mengatur pergerakan silia oleh karena itu berfungsi sebagai clearance mukosiliar. ${ }^{5}$

NO yang dihembuskan juga dapat berasal dari protonasi asam nitrit, yang melepaskan gas NO selama pengasaman. Sinus paranasal menghasilkan NO yang tinggi, karena didapatkan banyak inervasi serabut saraf dengan NSO1 terletak disekitar pembuluh darah hidung. ${ }^{5}$

Analisa elektrokimia dapat mengukur konsentrasi NO yang dihembuskan. The American Thoracic Society and European Respiratory Society telah merekomendasikan pemeriksaan NO dengan menghembuskan napas lewat hidung. Pemeriksaan ini dipengaruhi oleh demografi, faktor antropometri dan faktor biologi yang menyebabkan variasi hasil Fractional Exhaled nitric oxide ( $\mathrm{FE}_{\mathrm{no}}$ ). Pada perokok dapat menurunkan $\mathrm{FE}_{\mathrm{no}}$ dalam waktu yang pendek atau dalam waktu yang lama. eNOS dan iNOS keduanya dapat meregulasi $\mathrm{FE}_{\mathrm{no}}$. Peningkatan $\mathrm{FE}_{\mathrm{no}}$ disebabkan oleh karena peningkatan L-arginin, penggunaan bronkodilator seperti beta agonis. Penurunan $\mathrm{FE}_{\mathrm{no}}$ disebabkan oleh penggunaan inhalasi, oral kortiosteroid, dan bronkokonstriksi. ${ }^{3,6}$

Penggunaan $\mathrm{FE}_{\text {no }}$ direkomendasikan oleh ATS untuk:

1. Diagnosis inflamasi saluran napas dengan peningkatan eosinofil

2. Memprediksi respon individu dengan gejala napas kronik akibat inflamasi saluran napas terhadap steroid

3. Diagnosis asma pada keadaan yang membutuhkan bukti obyektif sebagai penunjang diagnostik

4. Memperhitungkan umur sebagai faktor yang mempengaruhi $F_{\text {no }}$ pada anak dengan usia dibawah 12 tahun

5. Kadar $\mathrm{FE}_{\mathrm{no}}$ lebih dari 50 ppb (>35 ppb pada anak merupakan indikasi terjadinya inflamasi dengan kadar eosinofil yang tinggi, dan respon terhadap kortikosteroid yang baik)

6. Kadar $F E_{\text {no }}$ kurang dari 25 ppb (<20 ppb pada anak menunjukkan kejadian inflamasi dengan kadar eosinofil yang lebih rendah dan respon terhadap kortikosteroid yang rendah )

7. Kadar FE $\mathrm{E}_{\text {no }}$ antara $25-50$ ppb (20-35 ppb pada anak harus diinterpretasi dengan hati-hati dan disesuaikan dengan keadaan klinis

8. Paparan alergen yang tinggi atau persisten harus dipertimbangkan berhubungan dengan kadar $F E_{n o}$ yang tinggi

9. $\mathrm{FE}_{\mathrm{no}}$ digunakan untuk memonitor inflamasi saluran napas pada pasien asma.

10. Peningkatan signifikan dari $\mathrm{FE}_{\text {no }}$ ditandai dengan meningkat $>20 \%$ untuk kadar diatas 50 ppb. Atau $>10 \%$ untuk kadar dibawah 50 ppb antara satu kunjungan dengan kunjungan yang lainnya
11. Pengurangan minimal $20 \%$ pada kadar $F E_{n o}$ diatas 50 ppb atau > 10 ppb pada kadar di bawah 50 ppb merupakan indikasi terhadap respon inflamasi yang signifikan. ${ }^{7}$

Meskipun NO adalah suatu radikal, namun reaktifitasnya relatif rendah. Sebagian besar NO berguna untuk melindungi cedera dan reaksi inflamasi. Wink dkk, tahun 1996 melaporkan NO bersifat oksidan. NO dapat bereaksi dengan radikal alkoksil dan peroksil intermediet untuk menghambat oksidasi yang diinduksi reaksi radikal lipid, dengan demikian dapat menghambat peroksidasi radikal lipidbebas. NO juga terbukti dapat menghambat produksi anion superoksida oleh neutrofil dengan menghambat NADH oksidase. NO juga dapat menghambat neutrofil dengan menghambat produksi neutrofil, selain itu NO dapat menghambat adhesi molekul endotel, NO dapat menurunkan produksi interleukin 8 yang merupakan suatu kemokin oleh sel epitel paru, dan menghambat aktifasi nuklear faktor kappa B (NF-kB) pada respon stimulasi inflamasi, seperti silika, LPS. ${ }^{5}$

NF-kB merupakan faktor transkripsi untuk berbagai sitokin inflamasi, kemokin dan faktor pertumbuhan, NO bisa menjadi pelindung terhadap efek patogen dari silika atau lipopolisakarida. Aktivasi NF-kB telah dikaitkan dalam peningkatan NO menghasilkan produksi Tumor Nekrosis Faktor alpha (TNF- $\alpha$ ), interferongamma (IFN- $\gamma$ ), dan merangsang produksi prostaglandin $\mathrm{E}_{2}\left(\mathrm{PGE}_{2}\right)$ oleh makrofag alveolar paru dan fibroblas paru. ${ }^{5}$

\section{Hidrogen Peroksida}

Hidrogen peroksida $\left(\mathrm{H}_{2} \mathrm{O}_{2}\right)$ adalah molekul yang terdeteksi dalam saluran pernapasan. Berbagai penelitian telah melaporkan bahwa peningkatan $\left(\mathrm{H}_{2} \mathrm{O}_{2}\right)$ terkait dengan berbagai penyakit paru, $\mathrm{H}_{2} \mathrm{O}_{2}$ merupakan penanda biomarker non invasif terhadap inflamasi dan stres oksidatif. $\mathrm{H}_{2} \mathrm{O}_{2}$ dihasilkan oleh enzim superoksida dismutase (SOD) pada saluran napas atas dan saluran napas. Sehingga dapat menjadi enzim pertahanan lini pertama untuk melindungi saluran pernapasan terhadap stres oksidan. ${ }^{8}$

Xantin oksidase, sitokrom $\mathrm{P} 450$ yang dapat mengurangi dan mengubah $\mathrm{O}_{2}$ menjadi $\mathrm{H}_{2} \mathrm{O}_{2}$, dan flavoenzim bertindak sebagai oksidase dengan menggunakan pengurangan NADPH. Pada individu yang sehat, produksi $\mathrm{H}_{2} \mathrm{O}_{2}$ merupakan proses reduksi oksigen oleh karena transport elektron di dalam mitokondria.

Transfer elektron mitokondria dilakukan secara langsung atau dikatalisis oleh SOD sitosol dalam reaksi cepat anion super oksida dengan air dan derivat proton. ${ }^{9}$

Produksi $\mathrm{H}_{2} \mathrm{O}_{2}$ didapatkan dari meningkatnya aktivitas fagsitosis NADPH oksidase dalam leukosit polimorfonuklear, monosit, makrofag, limfosit $\mathrm{B}$ dan sel endotel. Sebaliknya, degradasi $\mathrm{H}_{2} \mathrm{O}_{2}$ terjadi pada beberapa lokasi seluler karena katalase dan peroksidase. Katalase megonversi $\mathrm{H} 2 \mathrm{O}$ menjadi air melalui reaksi. ${ }^{9}$

Peroksidase juga mampu mengikat $\mathrm{H}_{2} \mathrm{O}_{2}$ untuk mempresentasikan enzim ke bakteri dan pengurangan $\mathrm{H}_{2} \mathrm{O}_{2}$ dapat digunakan untuk mengatalisa sejumlah 
reaksi oksidatif. Superoksida bersifat labil, namun $\mathrm{H}_{2} \mathrm{O}_{2}$ merupakan suatu volatile lebih stabil dan memasuki fase gas pada suhu normal. Oleh karena itu dapat diukur dengan tes florensensi, dengan menggunakan subtrat oksida oleh $\mathrm{H}_{2} \mathrm{O}_{2}$. Dengan metode ini beberapa peneliti menemukan peningkatan exhaled breath condensate (EBC) $\mathrm{H}_{2} \mathrm{O}_{2}$ pada pasien asma, PPOK, ARDS, kistik fibrosis, kanker paru, dan EBC pada perokok. Konsentrasi $\mathrm{EBC} \mathrm{H}_{2} \mathrm{O}_{2}$ meningkat saat terjadi eksaserbasi dari asma dan $\mathrm{PPOK}^{9}$

Pada PPOK terjadi penurunan $\mathrm{H}_{2} \mathrm{O}_{2}$ setelah pemberian steroid, dan pemberian jangka panjang $\mathrm{N}$-asetilsistein. Penurunan $\mathrm{H}_{2} \mathrm{O}_{2}$ menunjukkan karena terjadinya proses inflamasi (neutrofil dan makrofag) dalam darah perifer dan saluran udara. Sitokin inflamasi, aktifasi fagosit, endotel NADH oksidase yang terjadi berhubungan dengan konsentrasi $\mathrm{H}_{2} \mathrm{O}_{2}$ yang dihembuskan. Usia dan jenis kelamin mempengaruhi variabilitas hasil.

\section{Penyakit Paru Obstruktif Kronik (PPOK)}

PPOK merupakan penyakit paru yang dapat dicegah dan diobati, ditandai oleh hambatan aliran udara yang tidak sepenuhnya reversibel, bersifat progresif dan berhubungan dengan respon inflamasi paru terhadap partikel atau gas yang beracun/ berbahaya, disertai efek ekstra paru yang berkontribusi terhadap derajat penyakit. Karakteristik hambatan aliran udara pada PPOK disebabkan oleh gabungan antara obstruksi saluran napas kecil (obstruksi bronkiolitis) dan kerusakan parenkim (emfisema) yang bervariasi setiap individu. ${ }^{10}$

Potensi biomarker EBC tertentu pada PPOK adalah sebagai alat penunjang diagnostik, membedakan fenotif penyakit, memantau eksaserbasi,dan memonitor efek terapi pada PPOK. ${ }^{9,12}$

Inflamasi saluran napas pasien PPOK merupakan amplifikasi dari respon inflamasi normal akibat iritasi kronik seperti asap rokok. Mekanisme untuk amplifikasi ini belum diketahui, kemungkinan disebabkan faktor genetik. Pada pasien PPOK yang tidak mempunyai riwayat rokok, penyebab respon inflamasi yang terjadi belum diketahui. Inflamasi paru diperberat oleh stres oksidatif dan kelebihan proteinase. Semua mekanisme ini mengarah pada karakteristik perubahan patologis PPOK. ${ }^{10}$

Stres oksidatif dapat menjadi mekanisme penguatan penting dalam PPOK. Biomarker stress oksidatif (misalnya hidrogen peroksida,8-isoprostan) meningkat dalam sputum, konsedat hembusan napas dan sirkulasi sistemik pada pasien PPOK. Stres oksidatif lebih lanjut meningkat pada eksaserbasi. Oksidan yang dihasilkan oleh asap rokok dan partikulat yang dihirup lainnya yang dilepas dari sel-sel inflamasi (seperti makrofag dan neutrofil) diaktifkan. Mungkin juga ada penurunan antioksidan endogen pada pasien PPOK. Stres oksidatif memiliki beberapa konsekuensi yang merugikan di paru, termasuk aktivasi gen inflamasi, inaktifasi antiprotease, stimulasi sekresi mukus, dan stimulasi eksudasi plasma meningkat. Banyak dari efek samping di mediasi oleh peroksinitrat, yang dibentuk melalui interaksi antara anion superoksida dan oksida nitrat.
Oksida nitrat yang dihasilkan oleh oksida nitrat induktif, terdapat pada saluran napas perifer dan parekim paru pada pasien PPOK. ${ }^{10}$

Meningkatnya NO yang diekshalasikan pada PPOK mempunyai hubungan dengan meningkatnya jumlah eusinofil, meningkatnya respon dari bronkodilator, dan meningkatnya respon dari kortikosteroid. Namun, beberapa penelitian melaporkan terdapat peningkatan pada PPOK yang stabil, dan melaporkan tidak adanya perubahan ataupun berkurang. ${ }^{12}$

Hal ini berlawanan, kemungkinan dapat dijelaskan oleh anion superoksida, yang dihasilkan pada waktu stres oksidatif menggabungkan NO untuk membentuk peroksinitrit yang sangat reaktif. Isomer anionik yang tidak stabil dapat membentuk nitrat (NO3) sehingga meningkatkan kadar EBC pada pasien PPOK. Selain itu produksi nitrat juga meningkatkan nitrasi tirosin di perifer paru. Hal tersebut dapat menjelaskan mengapa $\mathrm{FE}_{\mathrm{no}}$ berkurang pada perokok dibandingkan tidak perokok. Selain itu, pasien dengan PPOK yang tidak stabil memiliki konsentrasi NO tinggi daripada perokok ataupun riwayat merokok dengan PPOK stabil. Hal tersebut terjadi karena reaksi inflamasi dan ketidakseimbangan antara oksidan antioksidan. Inhibitor NSO2 dapat mengurangi konsentrasi NO yang diekshalasi pada pasien asma dan orang normal dibandingkan dengan pasien PPOK. ${ }^{12}$

Brindicci, dkk tahun 2005 menemukan hubungan antara NO alveolar (calv NO) dan FEV1, dan tiffeneau index (FEV1/ FVC rasio). Calv NO merupakan indikator pasien PPOK dengan proses inflamasi dan remodelling dari saluran pernapasan. Meningkatnya NO diperifer disebabkan karena meningkatnya NOS1 dan aktifasi NOS2 pada pasien PPOK. Beberapa penelitian melaporkan meningkatnya NSO2 pada perifer paru dan saluran napas kecil. Produksi NSO3 berkurang di perifer paru pada pasien PPOK, terutama karena terjadinya emfisema, kerusakan dinding alveoli. Menurunnya NSO3 menyebabkan induksi sintesa NO di perifer paru pada pasien PPOK. Oleh karena itu NO diperifer terbukti menjadi biomarker non-invasif yang berguna pada inflamasi PPOK. ${ }^{12}$

Biomarker yang bersifat nonvolatile seperti hidrogen peroksida dan 8-isoprostan dapat dideteksi pada EBC. $\mathrm{H}_{2} \mathrm{O}_{2}$ meningkat pada EBC pasien PPOK dan pada pasien akut eksaserbasi PPOK. Ekshalasi $\mathrm{H}_{2} \mathrm{O}_{2}$ diproduksi setelah periode 3 hari. Pada suatu penelitian, pasien PPOK menghembuskan $\mathrm{H}_{2} \mathrm{O}_{2}$ sepuluh kali lebih banyak dari tanda subjek sehat, tetapi tidak didapatkan perbedaan jika status merokok dimasukkan. Pada suatu penelitian prospektif yang bertujuan untuk menilai variabilitas 21 hari atau sirkadian dari $\mathrm{H}_{2} \mathrm{O}_{2} \mathrm{EBC}$, pasien PPOK stabil ringan memiliki kadar $\mathrm{H}_{2} \mathrm{O}_{2}$ yang serupa dengan kelompok kontrol. Hasil penelitian ini mendukung penelitian sebelumnya yang menunjukkan bahwa kadar $\mathrm{H}_{2} \mathrm{O}_{2}$ hanya ditemukan pada kasus PPOK sedang dan berat. ${ }^{13}$

$\mathrm{H}_{2} \mathrm{O}_{2}$ meningkat pada perokok dengan melepaskan neutrofil dan makrofag pada saluran pernapasan bawah. $\mathrm{H}_{2} \mathrm{O}_{2}$ mengonversi dalam radikal hidroksil dan menyebabkan 
peroksidasi dari asam lemak tak jenuh dalam membran sel. Selain itu dapat meningkatkan stres nitrosatif pada PPOK yang ditunjukkan dengan peningkatan konsentrasi nitrit dan nitrosothiols di EBC. ${ }^{13}$

\section{Asma Bronkiale}

Asma merupakan gangguan inflamasi kronik saluran pernapasan yang melibatkan berbagai sel inflamasi dan elemennya yang berhubungan dengan hipereaktifitas bronkus, sehingga menyebabkan episodik berulang seperti mengi, sesak napas, rasa berat di dada, dan batuk terutama malam atau dini hari. Episodik perburukan tersebut berkaitan dengan luasnya peradangan, variabilitas, beratnya obstruksi jalan napas yang bersifat reversibel baik spontan maupun dengan pengobatan. ${ }^{14}$

Inflamasi saluran pernapasan bersifat kronik dan persisten tetapi memberikan gejala yang episodik. Hubungan intensitas inflamasi dan beratnya asma secara klinis adalah belum jelas. Inflamasi yang terjadi meliputi seluruh sistem saluran pernapasan termasuk saluran pernapasan atas (united airway disease), tetapi efek fisiologinya dominan terlihat pada saluran pernapasan bawah. ${ }^{14}$

Pola inflamasi pada berbagai bentuk asma (asma alergik, non alergik, asma akibat aspirin, asma pada exercise) adalah sama pada semua usia. Sel inflamasi yang terlibat adalah sel mast, eosinofil, limfosit T terutama Th2, sel dendritik, makrofag, dan neutrofil. Sedangkan sel struktur jalan napas yang terlibat dalam produksi mediator inflamasi dan berkontribusi dalam proses inflamasi kronik adalah sel epitel jalan napas, sel otot jalan napas, sel endotelial pembuluh darah bronkus, sel fibroblas, miofibroblas dan serabut saraf jalan napas. Selain itu terdapat ratusan mediator yang terlibat dalam proses inflamasi yang kompleks pada asma antara lain kemokin, sistenil leukotrien, sitokin histamin, oksida nitrat/ NO, dan prostaglandin D2. ${ }^{14}$

Inflamasi saluran pernapasan eusinofilik pada penelitian sebelumnya yang melibatkan pasien asma dengan kadar eosinofil yang tinggi menunjukkan kadar $F_{E_{n}}$ sebagai biomarker. Kadar prediktif $\mathrm{FE}_{\mathrm{no}}$ lebih dari25 ppb merupakan indikator kuat untuk mediagnostik asma. Kadar prediktif $F E_{n o}$ tersebut lebih tinggi daripada spirometri dan peak flow meter. Secara umum peningkatan $\mathrm{FE}_{\mathrm{no}}$ untuk suportif dalam diagnostikakan tetapi bukan merupakan standar emas pada penderita dengan keluhan batuk, mengi, dan, sesak napas bervariasi, sehingga banyak yang tidak terdeteksi pada pemeriksaan $\mathrm{FE}_{n \mathrm{n} .}{ }^{13}$

Keterbatasan dari $\mathrm{FE}_{\mathrm{no}}$ dalam diagnostik disebabkan oleh karena inflamasi saluran napas pada asma bersifat heterogen dan tidak selalu berhubungan dengan peningkatan $\mathrm{FE}_{\mathrm{no}}$ misalnya inflamasi saluran napas oleh karena produksi neutrofil yang tinggi. Oleh karena itu peran penting dari $\mathrm{FE}_{\mathrm{no}}$ adalah dalam mengidentifikasi respon penderita terhadap steroid. ${ }^{13}$

Pada penderita tanpa gejala termasuk pada penderita dengan asma terkontrol penuh, kadar $\mathrm{FE}_{\text {no }}$ yang rendah menunjukkan bahwa dosis kortikostroid inhalasi dapat diturunkan atau bahkan dihentikan. Pada penelitian misalnya penelitian terhadap anak-anak yang menderita asmastabil, pemberhentian kortikosteroidinhalasi tidak menyebabkan kambuhnya gejala bila kadar $\mathrm{FE}_{\text {no }}$ secara konsisten rendah ketika diperiksa 2-4 minggu setelah terapi dihentikan. Pada pederita yang memiliki gejala dengan kadar $\mathrm{FE}_{\mathrm{no}}$ yang rendah strategi selain meningkatkan dosis kortikosteroid inhalasi harus dilakukan. Sebagai prediktor kontrol asma $\mathrm{FE}_{\mathrm{no}}$ tidak lebih baik daripada pemeriksaan fungsi

\section{KESIMPULAN}

Biomarker belum memiliki definisi yang universal, akan tetapi biomarker dipahami sebagai suatu biomolekul yang timbul akibat suatu proses fisiologi maupun patologi. Biomarker yang ideal adalah suatu biomarker yang tidak dapat dideteksi atau nilainya rendah dalam keadaan non inflamasi, dan akan meningkat dalam keadaan inflamasi yang selanjutnya akan mengalami penurunan saat proses inflamasi mereda. NO adalah suatu radikal, namun reaktifitasnya relatif rendah. Sebagian besar NO berguna untuk melindungi cedera dan reaksi inflamasi. Berbagai penelitian telah melaporkan bahwa peningkatan $\left(\mathrm{H}_{2} \mathrm{O}_{2}\right)$ terkait dengan berbagai penyakit paru, $\mathrm{H}_{2} \mathrm{O}_{2}$ merupakan penanda biomarker non invasif terhadap inflamasi dan stres oksidatif.

Stres oksidatif dapat menjadi mekanisme penguatan penting dalam PPOK. Biomarker stress oksidatif ( misalnya hidrogen peroksida, 8-isoprostan) meningkat dalam sputum, EBC dan sirkulasi sistemik pada penderita PPOK. Stres oksidatif lebih lanjut meningkat pada eksaserbasi. Keterbatasan dari $F_{n}$ dalam diagnostik disebabkan oleh karena inflamasi saluran napas pada asma bersifat heterogen dan tidak selalu berhubungan dengan peningkatan $F_{n}$ misalnya inflamasi saluran napas oleh karena produksi neutrofil yang tinggi. Oleh karena itu peran penting dari $\mathrm{FE}_{\mathrm{no}}$ adalah dalam mengidentifikasi respon penderita terhadap steroid

\section{DAFTAR PUSTAKA}

1. Cao W, Duan Y. Breath analysis: potential for clinical diagnosis and exposure assesment. Clin Chem 2006: 52: 800.

2. Abba AA. Exhalled nitric oxide in diagnosis and management of respiratory dissease. Ann thorac med 2009: 4: 173.

3. Miekisch W, Schubert JK, Noeldge-Schomburg GFE. Diagnostic potential of breath analysis focus on volatile organic compound. Clin Chim Acta 2004;347: 25-29.

4. Guibault GG, Palleschi G, Lubrano G. non invasive biosensor in clinical analysis. Biosens bielectron 1995;10: 379.

5. Patti C, Zeidler, Vincent $C$, Role of NO in pathological respon of the lung to exposure enviromental 2003; 9: 1.

6. Hoyt JC, Robbins RA,Habib M. Cigarette smoke decreases inducible ntric oxide synthase in ung epitelial cells. Exp Lung Res 2003;29: 267.

7. Raed A, Dweik, Peter B. An official ATS clinical practice guidline: interpretation of exhaled NO levels (Feno) for clinical application. Clin.practice guidline the ATS 2011. 
8. Stolarek R. Breath analysis hidrogen peroxide as a diagnostic tool. Clin Chim Acta 2010; 411: 1849.

9. Djordjevic T . NOX5 variants are functionally active in endothelial cells. Free Radic Biol Med 2007;42: 446.

10. Perhimpunan Dokter Paru Indonesia. PPOK diagnosa dan penatalaksanaan juli2011; 11-1.

11. Borrill ZL, K.Roy, D.Singh. Exhaled breath condensate biomarkers in COPD. Eur jurnal J 2008;32: 472-486.
12. Meigu Z, smith AD. Breath Biomarker in diagnosis of pulmonary disease. Clinical Chimica Acta 2012;1770-178.

13. Van $B, A$ robbins. Variability of exhaled hydrogen peroxide in stable COPD patients and matched healthy controls. Respiration 2002;69: 211-6.

14. Dewan Asma Indonesia. Pedoman Tatalaksana Asma 2011;1-6. 